\title{
INTEGRATION OF REASON AND REVELATION IN THE PERSPECTIVE OF PHILOSOPHY OF SCIENCE
}

\author{
Dadang Mustopa \\ Program Studi Pendidikan Agama Islam \\ Fakultas Agama Islam Universitas Islam Nusantara Bandung, Indonesia \\ Email: dadangmustopa@uninus.ac.id
}

\begin{abstract}
Reason is a primary instrument that God created in humans. With reason, one can reason, analyse, and give birth to innovative, creative, and varied ideas. Today the social stratification of a person and his strategic position in the community are often determined by the product of the mind that is born - mainly related to the world of science and modern technology. However, in the perspective of the Qur'an, the mind is not everything. Because at a certain level, competence and reasoning, power cannot afford to reach it. Notably, if it is correlated with the issue of religious truth absolutism, then one cannot rely solely on his reason. Therefore, God revealed revelation as a definitive reference in establishing absolute truth. The announcement that God sent down in no way contradicts a healthy mind. In fact, between revelation and reason can synergize in determining which are good and which are bad, which are right and which are wrong. At the same time, the idea cannot be arrogant but must be submissive and obedient to revelation. Therefore, the reason is never satisfied with a truth that is received without proof rationally. To strengthen the faith in the revelation of God and to provide an explanation for those who doubt, a revelation needs the role of reason to reveal the truths brought about by revelation. With the ability of reason to confirm the fact brought by revelation rationally, then the truth revelation will be more readily accepted by humans by the signs determined by revelation.
\end{abstract}

Keywords: Reason; Revelation; Philosophy of Science; Truth

\section{A. INTRODUCTION}

Reason and revelation have a significant role in the journey of human life (Bakhshizadeh, 2018, p. 121). The revelation sent down by God to human beings as a clue to navigate the experiences of life in this world (Guerra, 2001, p. 4). Intellect is not necessarily able to understand God's revelation, are the five human senses that accompany it to be able to understand the revelations revealed by God (Newbegin, 2011, p. 117). Thus, there is a close relationship between revelation as absolute truth because it comes from God with the journey of human life (Sonn, 2005, p. 68).

When speaking of relations between reason and revelation, then certainly talking about philosophy and religion. Although each religion and philosophy depart from a different foothold, faith withdraws from the foundation of belief, while philosophy begins with doubts and questions (Schilling, 1948). It cannot be doubted and denied that reason has a position in the territory of Islam. What is essential in this case is determining and explaining the limits of reason, because we all believe that almost all Muslims try and try to benefit the mind in Islamic teaching and explanation argumentative religious beliefs (Hourani, 2007, p. 118). 
The relationship of reason and revelation is always recognized to cause problems such as the function and connection of reason to revelation in obtaining knowledge (Griffel, 2018). According to Harun Nasution, what is needed is an effort to rationalize the understanding of Muslims who are judged dogmatically, which causes the decline of Muslims because of the lack of optimizing the potential of the mind possessed. Departing from this view, it is necessary to look for the integration of reason and revelation in the perspective of the philosophy of science (Nasution, 1986, p. 1).

\section{B. METHOD}

The type of research that will be used is library research (Beasley, 2000, p. 117). The study was conducted by taking the data sources by examining the books of Islamic thought that are concerned with Reason and Revelation. The research approach taken is a philosophical approach means a procedure that uses philosophy. Philosophy is to think deeply, systematically, radically, and universally to find the core truths of wisdom or essence regarding everything that exists (Zaelani, 2015).

\section{RESULT AND DISCUSSION}

Jamil Shaliba in al-Mu'jam al-Falsafī gives the meaning of 'aql literally in terms of al-imsāk (holding), al-ribāț (bond), al-hijr (holding), al-nahy (forbidding) and al-man' (prevent). A person who has reason (al-'áqil) is a person who restrains himself and holds back the desires of his desires (Șalibā, 1982, p. 84). While the Qur'an mentions approximately 49 words 'aql which appear varied. All these words are expressed in the form of verbs (fi'l) and are never said in mașdar form, but they all come from the primary word 'aql.

The word 'aql, in the era of ignorance is used in the sense of practical intelligence which in terms of modern psychology is called problem solving capacity. People who think intelligently are people who have the ability to solve the problems they face (Nasution, 1982, pp. 7-8) Therefore, the word 'aq/ has many meanings. Philosophically, reason is the power of intellect with the nature to know everything. It is believed that reason also has many activities.

These activities are al-nazar (seeing with attention), al-tadabbur (paying close attention), alta'ammul (contemplating), al-istibșār (seeing with the inner eye), al-i'tibār (interpreting), altafkir (thinking), and al-tadhakkur (remembering) (Yudiani, 2013). Thus, 'aql has several functions, but the most important is as first intelligence, that is inherent and divine knowledge that is instilled in human beings, or can be said as fitrah. However, humans cannot automatically use this potential mind. Humans must develop the potential of their soul so that the right brain can be achieved and used according to its function, namely thinking.

Revelation in the Koran is taken from the word wahy which has several meanings such as speed, whispers and gestures. But the word wahy is better known in the sense of "what God said to his prophets. Revelation in sharia terms is the word of God sent down to his prophets and apostles, whether through the intermediary Gabriel or not (Șalibā, 1982, p. 570). While the revelation serves to provide information to humans about matters of belief, thank God and provide general provisions regarding the deeds established by Sharia (Muhaimin, 2000, pp. 29-31).

Revelation in the view of the theologians, such as the followers of Ash'ārī have the most important position in the sect (Lapidus, 2002, p. 166), while Mu'tazili prefers reason rather than revelation, in the sense of the domain of revelation under the domain of reason. The greater the domain of revelation that is played, the smaller the role of reason in a stream, on 
the contrary the greater the domain of reason that is played, the smaller the domain of revelation played in a stream. Intellect in the effort to acquire knowledge, acts on its own effort and power, thereby describing human independence and ability (Morrison, 2013, p. 160). Revelation, on the other hand, describes human weakness, because revelation was revealed by God to help humans obtain their knowledge (Yusuf, 2016, p. 65).

It is speaking of reason and revelation, of course expressing philosophy and religion (Masbukin \& Hassan, 2017). These two terms there is a meeting point in the same field, namely what is called "the Ultimate Reality," which is most famous for the problem of life and human death (Annalakshmi \& Abeer, 2011). The distance that distinguishes, between the two, does not lie in the field that becomes the meeting point itself but lies in how to investigate the area.

Among the differences are: (1) If the priority in philosophy is "thinking," then in religion is serving; (2) if philosophy emphasizes knowledge to "understand," then faith requires knowledge to "worship."; (3) if in philosophy it is contemplation (for example thinking about what is "love"?), then enjoyment is done in religion (feeling and experiencing "love" itself); (4) philosophy even though it is calm in realizing it, but often muddying the mind of its adherents, while religion fulfills its followers with enthusiasm and feeling of self-service but the effect calms the soul of its followers; and (5) if philosophy has a lot to do with reason or mind, then religion has a lot to do with the heart (Trueblood, 1994, pp. 3-4)

Both philosophy and religion determine good and bad norms, but both are different in determining the criteria for something that is called good and evil (Ayala \& Arp, 2009, p. 322). On the one hand, belief in measuring the requirements of good and evil is based on the teachings of revelation, while philosophy seeks criteria by doing a thought process to find knowledge using the human mind.(Bicchieri, Muldoon, \& Sontuoso, 2018).

Human reason, even though it has substantial reach and analytical power, but it is still relative and limited because it is unable to reach all the problems faced by humans ultimately. Human reason can change so that the decisions it produces can also change (Mienaltowski, 2011). A theory that is considered right by basis this year could have been several years or other times that were no longer said to be accurate; on the contrary, it was considered a false theory. With such limitations, the truth produced by reason is relative truth (relative) (Gazalba, 1992, p. 24), or referred to by Endang Saifudin Ansari as speculative truth (Anshari, 1982, p. 174).

Ibn Rushd tried to answer the integration of reason and revelation in his work Fașl al-Maqāl. These two sources of truth are often contested by orthodox scholars. Ibn Rushd began in his book with a few simple questions: is using reason-mind contrary to religion and is learning Philosophy forbidden in Islam? Through sharp analysis and arguments, Ibn Rushd replied that there was no conflict between religion and reason, and there was also no prohibition in Islam to study philosophy (Habti, 2011).

Ibn Rushd's argument in expressing this answer was that reason, and revelation were both gifts of God. Both are inseparable, borrowing Ibn Rushd's terms, reason and revelation like "brothers" that cannot be separated. Intellect requires admission because there are problems in this world, especially those related to the supernatural (metaphysics), which cannot be reached by reason. While revelation also requires reason because, without reason, revelation cannot be understood (Rushd, n.d., pp. 22-24) 
Ibn Rushd respected reason because, without reason, the verses of the Qur'an and the purpose of human creation, in general, do not have much meaning. Intellect and al-Quran cannot be contested. If we encounter verses from the Qur'an which seem to contradict reason, according to Ibn Rushd, the verses need to be excluded, as he explicitly said in his Fasl al-Maqal: if there is no conflict between revelation and reason, interpretation is not required, but if there is opposition, then revelation needs to be interpreted (Rushd, n.d., pp. 32).

Ibn Țufayl, in his philosophical novel Hayy Ibn Yaqzān, explained that the achievement of knowledge about God is two ways to know him, that is, using reason or using Sharia (Masudi, 2015). These two paths are not contradictory because the end of philosophy is the attainment of knowledge about God. Ibn Tufayl describes to humans that trust in God is a part of human nature that cannot be denied, and a healthy mind by observing and contemplating the surrounding world will certainly come to God (Sudarsono, 2004, p. 81).

From the description above, it is clear that the fundamental difference between religion and philosophy lies like the correct value as a result of gaps in the primary sources of each. On the one hand, philosophy has a relative or speculative truth value because it comes from something relatively too, namely human reason (Nielsen, 1995, p. 25). Whereas on the other hand, the truth value of religion becomes absolute and eternal because it comes from something infinite and eternal, namely God (Vries, 2009, p. 352). Although there are fundamental differences in both, that does not mean that both of them have absolutely no tangent points or cannot greet each other and reciprocate closely.

To obtain the truth of knowledge, philosophy can be a tool to explain and strengthen the position of religion, while religion can be a source of inspiration for the emergence of reliable and correct philosophical thinking (Wen, 2014, p. 12). Not a few reflective thoughts turned out to lead to the belief in the existence of God, an essential characteristic of religion as a system of trust in God, so that not a few philosophers were stronger in their faith after doing philosophical odyssey in the world they wrestled deeply (Morris, 1994, p. 27).

If observed, it can be seen that the main reason for the denial of religion and God on some philosophers is because of their limited reasoning which is unable to reach the level of faith in its journey to explore the actual reality. Besides this primary cause, it is also influenced by other roots, such as the background of the life and social environment of the philosopher in question. And the most important reason, according to the religious view, is the guidance of God. Only the philosopher who gets advice from God will arrive at the phase of faith at the end of the philosophical odyssey of that mind (Morris, 1994, p. 28).

Furthermore, religion and philosophy, indeed epistemologically is often positioned in different places, facing each other and even contradicting. It is usually based on the view that the epistemological basis of both is indeed different, because religion comes from faith in God's revelation, while philosophy rests on human rationality. These two different spaces are what make the conversation about the relationship between the two, never boring and never finished. Moreover, the definitive formulation of religion and philosophy has not yet reached an agreed formula. It can be said that the number of definitions of both is as much as the person who defines it (Heidegger, 2004, p. 53).

M. Amin Abdullah describes the relationship between Philosophy and religion with what he calls the first level of discourse, namely in the level of general scientific discussion. By borrowing the term Wittgenstein, Abdullah said that philosophy and religion both had their 
form of life, so it was somewhat difficult for us to map the relations between them. From this research, Abdullah concluded that the difficulty was found to be in the form of a format of the relationship between "conception," which represented religion and "conception" that represented philosophy (Abdullah, 1995, p. 117).

In one condition, the "conception" of religion is often felt more accurate, but in certain conditions precisely the "conception" of philosophy is explored more accurate than the conception offered by faith. There are even certain philosophical schools that eliminate and reduce the role of metaphysics and ethics, which are very dominant in religious thought. If this disharmony of religious and philosophical relations enters the next level, the second discourse, which is coming into the relationship between "certain" religion and philosophy in general, then the situation of this disharmony will become increasingly apparent.

Abdullah pointed out, in the history of Islam's religious experience, especially after the dominance of Islamic orthodoxy, the spirit and light of philosophical thought became increasingly dim among Muslims. Al-Ghazali's rejection of philosophy and Muslim philosophers, such as Ibn Sina and al-Farabi, had an impact on the emergence of the traumatic situation of Muslims towards philosophical thought so that there was a ban on philosophy (Abdullah, 1995, p. 117).

\section{CONCLUSION}

In the discussion of reason and revelation, there is a space where both of them can meet, even greet each other and make out, but there is also space where they must separate. At the time the revelation recommended the development of science and culture by giving space to the freedom of reason to think dynamically, creatively and openly, that was where space met and made sense between reason and revelation.

The reason is a tool for thinking and philosophizing that aims to find the truth. Intellect activity is the power in searching for truth, which is an object of thought that never runs out. Therefore, the reason is never satisfied with a reality that is received without proof rationally. To strengthen the faith in the revelation of God and to provide an explanation for those who doubt, a revelation needs the role of reason to reveal the truths brought about by revelation. With the ability of reason to validate the authenticity brought by revelation rationally, the reality of revelation will be more readily accepted by humans following the signs determined by revelation.

\section{REFERENCES}

Abdullah, M. A. (1995). Falsafah Kalam di Era Postmodernisme. Yogyakarta: Pustaka Pelajar.

Annalakshmi, N., \& Abeer, M. (2011). Islamic worldview, religious personality and resilience among Muslim adolescent students in India. Europe's Journal of Psychology, 7(4), 716-738-738. https://doi.org/10.5964/ejop.v7i4.161

Anshari, E. S. (1982). IImu, Filsafat dan Agama. Surabaya: Bina Imu.

Ayala, F. J., \& Arp, R. (2009). Contemporary Debates in Philosophy of Biology. West Sussex: John Wiley \& Sons.

Bakhshizadeh, M. (2018). Changing Gender Norms in Islam Between Reason and Revelation. Opladen - Berlin - Toronto: Verlag Barbara Budrich. 
Beasley, D. R. (2000). Beasley's Guide to Library Research. Toronto - Buffalo - London: University of Toronto Press.

Bicchieri, C., Muldoon, R., \& Sontuoso, A. (2018). Social Norms. In E. N. Zalta (Ed.), The Stanford Encyclopedia of Philosophy (Winter 2018). Retrieved from https://plato.stanford.edu/archives/win2018/entries/social-norms/

Gazalba, S. (1992). Sistematika Filsafat. Jakarta: Bulan Bintang.

Griffel, F. (2018). Ibn Taymiyya and His Ash'arite Opponents on Reason and Revelation: Similarities, Differences, and a Vicious Circle. The Muslim World, 108(1), 11-39. https://doi.org/10.1111/muwo.12228

Guerra, M. D. (2001). The Christian Aristotelianism of james Schall. In M. D. Guerra (Ed.), Reason, Revelation, and Human Affairs: Selected Writings of James V. Schall. Maryland - Oxford: Lexington Books.

Habti, D. (2011). Reason and Revelation for an Averroist Pursuit of Convivencia and Intercultural Dialogue. Policy Futures in Education, SAGE Publications, 9(1), 81-87. https://doi.org/10.2304/pfie.2011.9.1.81

Heidegger, M. (2004). The Phenomenology of Religious Life. Bloomington - Indiana: Indiana University Press.

Hourani, G. F. (2007). Reason and Tradition in Islamic Ethics. Cambridge: Cambridge University Press.

Lapidus, I. M. (2002). A History of Islamic Societies. Cambridge: Cambridge University Press.

Masbukin, M., \& Hassan, A. (2017). AKAL DAN WAHYU; Antara Perdebatan dan Pembelaan dalam Sejarah. TOLERANSI, 8(2), 152-169.

Masudi, M. (2015). PEMIKIRAN FILSAFAT IBNU THUFAIL (Khazanah Pemikiran Filsafat dari Timur Asrar al-Hikmat al-Masyriqiyyah). FIKRAH, 3(2), 411-430. https://doi.org/10.21043/fikrah.v3i2.1822

Mienaltowski, A. (2011). Everyday problem solving across the adult life span: solution diversity and efficacy. Annals of the New York Academy of Sciences, 1235, 75-85. https://doi.org/10.1111/j.1749-6632.2011.06207.x

Morris, T. V. (1994). God and the Philosophers: The Reconciliation of Faith and Reason. Oxford: Oxford University Press.

Morrison, R. G. (2013). Islamic Perspectives on Natural Theology. In R. R. Manning (Ed.), The Oxford Handbook of Natural Theology. Oxford: OUP Oxford.

Muhaimin. (2000). Pembaharuan Islam: refleksi pemikiran Rasyid Rida dan tokoh-tokoh Muhammadiyah. Bandung: Pustaka Dinamika.

Nasution, H. (1982). Akal dan Wahyu dalam Islam. Jakarta: Penerbit Universitas Indonesia.

Nasution, H. (1986). Teologi Islam: Aliran-aliran Sejarah Analisa Perbandingan. Jakarta: Penerbit Universitas Indonesia.

Newbegin, T. L. (2011). The Book of Revelation: a New Beginning. Bloomington: Balboa Press.

Nielsen, K. (1995). On Transforming Philosophy: A Metaphilosophical Inquiry. Boulder: Westview Press.

Rushd, I. (n.d.). Fașl al-Maqāl. al-Qāhirah: Dār al-Ma'ārif. 
Șalibā, J. (1982). al-Mu'jam al-Falsafi, Vol. II. Bayrūt: Dār al-Kutub al-Lubnānī.

Schilling, S. P. (1948). Revelation and Reason. Journal of Bible and Religion, 16(1), 13-72. Retrieved from JSTOR.

Sonn, T. (2005). Islam and Modernity: Are They Compatible? In H. Malick \& S. T. Hunter (Eds.), Modernization, Democracy, and Islam. Washington DC: ABC-CLIO.

Sudarsono. (2004). Filsafat Islam. Jakarta: Rineka Cipta.

Trueblood, D. (1994). Philosophy of Religion (Filsafat Agama) (M. Rasjidi, Trans.). Retrieved from https://www.goodreads.com/book/show/6962105-filsafat-agama

Vries, H. de. (2009). Religion: Beyond a Concept. New York: Fordham Univ Press.

Wen, R. K. (2014). Philosophy: One Man's Overview. Bloomington: iUniverse.

Yudiani, E. (2013). DINAMIKA JIWA DALAM PERSPEKTIF PSIKOLOGI ISLAM PRA-PSIKOLOGI ISLAM (HAMKA, 1956) JIA/Juni 2013/Th.XIV/Nomor 1/PDF. Jurnal IImu Agama, 14(1), 4559.

Yusuf, Y. (2016). Alam Pikiran Islam Pemikiran Kalam. Jakarta: Prenada Media.

Zaelani, K. (2015). Philosophy of science actualization for Islamic science development: Philosophical study on an epistemological framework for Islamic sciences. Pacific Science Review B: Humanities and Social Sciences, 1(3), 109-113. https://doi.org/10.1016/j.psrb.2016.06.004 